\title{
POLITYKA
}

\section{Aleksandra Zamaraeva}

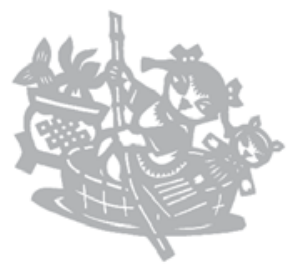

\section{INTERESY CHIN W AZJI CENTRALNEJ}

\section{Wstęp}

Chińska Republika Ludowa, jako mocarstwo co najmniej regionalne oraz sąsiad większości postradzieckich państw azjatyckich posiada, co jest naturalne, swoje interesy w regionie Azji Centralnej. Nie jest to kwestia nowa - Chiny wielokrotnie rywalizowały o te tereny, zwykle starały się mieć wpływ na sytuację w regionie. Można więc określić te interesy ,jako wieczyste”. Na ogół wymienia się wśród nich ${ }^{1}$ :

- zapewnienie bezpiecznych granic,

- niedopuszczenie do obecności w regionie siły wrogo nastawionej,

- nieskrępowany dostęp do surowców naturalnych².

Lata zimnej wojny i rywalizacji chińsko-radzieckiej były okresem, gdy wyżej określone interesy Chin w Azji Centralnej nie były realizowane. Sytuacja na granicy była napięta, sąsiadem było wrogie mocarstwo i nie było mowy o dostępie do surowców centralnoazjatyckich.

${ }^{1}$ D. Finkelstein, China's Emergence in Central Asia: Security, Diplomatic, and Economic Interests. Forum One: The Current State of China - Central Asia Diplomacy and Implications for U.S. Foregn Policy. Wednesday, February 5, 2003, [@:] http://:www.csis.org (12.11.2004).

${ }^{2} \mathrm{~W}$ zależności od sytuacji, interesy te realizowane były na trzy sposoby. Opisując je, David Finkelstein zastosował koncepcję „3 C”: co-opting, conquering, colonizing, czyli: współpraca, zawojowanie, kolonizacja. Ibidem. 
Sytuacja ta zmieniła się w 1991 r. Przed Chinami pojawiły się nowe możliwości aktywnego działania w Azji Centralnej, ale jednocześnie nowe zagrożenia i problemy, które spowodował rozpad Związku Radzieckiego. Państwo Środka potrzebowało czasu na przeanalizowanie zaistniałej sytuacji oraz wypracowanie polityki wobec nowo powstałych państw i skutecznych metod wobec nowych zagrożeń.

\section{Szanghajska Organizacja Współpracy jako instrument chińskiej poliłyki w regionie}

Mimo początkowych oznak dezorientacji władze chińskie stosunkowo szybko dostrzegły potrzebę nawiązania dobrych stosunków w nowo powstałymi państwami centralnoazjatyckimi. Jednak Pekin, podobnie jak i państwa Zachodu, nie był pewien ewentualnej reakcji Moskwy wobec jego polityki w tym regionie. $Z$ powodu obawy, że pogorszą się stosunki z Rosją, działania chińskie były początkowo bardzo powściągliwe. Dlatego pierwszym krokiem po nawiązaniu stosunków dyplomatycznych z państwami regionu w 1992 r. było rozstrzygnięcie problemu, który Chiny uważały za najbardziej drażliwy, czyli delimitacja wspólnych granic. Początkowe bilateralne rozmowy z Kazachstanem, Kirgistanem, Rosją i Tadżykistanem Chiny przekształciły w pięciostronne spotkania, których zasięg przestał ograniczać się wyłącznie do kwestii granicznych. Doprowadziło to do podpisania przez prezydentów tych państw w kwietniu 1996 r. w Szanghaju serii 14 porozumień dotyczących nie tylko kwestii terytorialnych i bezpieczeństwa granic, ale i spraw gospodarczych.

Porozumienia te, otrzymując wkrótce nazwę Układu Szanghajskiego, stały się podstawą utworzenia forum konsultacyjnego, na którym były dyskutowane propozycje techniczne związane $\mathrm{z}$ delimitacją granicy, tworzeniem środków budowy zaufania w strefach przygranicznych, a także zagadnienia handlu, transportu i migracji ludności. Ta stopniowo rozszerzająca się współpraca doprowadziła do efektów, bardzo często wykraczających i znacznie szerszych, niż uprzednio zaplanowane. Układ Szanghajski stworzył ramy umożliwiające dialog w dziedzinie polityki regionalnej. Od jego podpisania temat dyskusji na forum przesunął się w stronę regionalnej współpracy gospodarczej i bezpieczeństwa subregionu Eurazja Północna-Azja Centralna-Azja Zachodnia.

Chiny zaczęły traktować forum szanghajskie jako platformę do przekonywania państw centralnoazjatyckich do własnej racji stanu, a także do lansowania własnej wizji świata wielobiegunowego. W związku $\mathrm{z}$ tym za konieczną uznały instytucjonalizację spotkań i objęcie ich zasięgiem również innych państw centralnoazjatyckich. W rezultacie 14 i 15 czerwca 2001 r., na jubileuszowym szczycie „Piątki Szanghajskiej”, państwa członkowskie oraz Uzbekistan podpisały deklarację 
o utworzeniu nowej regionalnej wspólnoty: Szanghajskiej Organizacji Współpracy $(\mathrm{SzOW})^{3}$.

Powstała organizacja, która z punktu widzenia Pekinu, ma służyć jako jeden $\mathrm{z}$ instrumentów realizacji interesów chińskich i rozszerzania stabilnej regionalnej współpracy w Azji Centralnej. Obecnie można zdefiniować je w następujący sposób:

- kontynuacja delimitacji i zabezpieczenia granic;

- utworzenie mechanizmów regionalnych ukierunkowanych na zwalczanie terroryzmu, separatyzmu i ekstremizmu religijnego;

- uzyskanie pozycji jednego z najważniejszych aktorów w regionie;

- utworzenie fundamentów dla współpracy gospodarczej z państwami centralnoazjatyckimi.

\section{Współpraca w dziedzinie problemów granicznych}

Zachodnia granica Chin, której długość wynosi około 3400 km, jest granicą z 6 państwami: Rosją (40 km), Kazachstanem $(1533 \mathrm{~km})$, Kirgistanem $(858 \mathrm{~km})$, Tadżykistanem (414 km), Afganistanem (76 km) i Pakistanem $(523 \mathrm{~km})$. Cała jej długość po stronie chińskiej leży w obrębie prowincji autonomicznej Xinjiang, zamieszkanej głównie przez turkijskojęzyczną ludność muzułmańską ${ }^{4}$.

W 1991 r. liczba zachodnich sąsiadów Chin zwiększyła się z 3 do 6. Zmiany te były nie tylko ilościowe, ale i jakościowe. Wiązały się bowiem z nieprzewidywalnością kierunku rozwoju nowo powstałych państw. Oprócz tego niepewną sytuację w regionie starały się wykorzystać niektóre państwa trzecie, szerząc m.in. propagandę panturkijską. Za przykład może posłużyć artykuł ogłoszony na łamach ogólnokrajowej tureckiej gazety „Zaman”, którego autor sugerował rychłe utworzenie Islamskiej Republiki Turkiestanu z centrum w Ałmaty, która obejmowałaby między innymi te chińskie terytoria, których ludność mówi językami tureckimi. Wszystko to nie mogło nie zaniepokoić władz Chin i już w 1992 r. wystąpiły

\footnotetext{
${ }^{3}$ SzOW ogłosiła swoim celem wzmocnienie wzajemnego zaufania, przyjaźni i dobrego sąsiedztwa między państwami, a także popieranie efektywnej współpracy politycznej, gospodarczej, naukowej, technicznej, w dziedzinie kultury, wykształcenia, energetyki, transportu i handlu oraz popieranie i zabezpieczenie pokoju, bezpieczeństwa i stabilności w regionie. Hartiâ Šanhajskoj Organizacii Sotrudničestva, [@:] http://:www.rncpec.fareast.ru (15.01.2004).

${ }^{4}$ Negocjacje nad przebiegiem wtedy jeszcze radziecko-chińskiej granicy toczyły się w $1986 \mathrm{r}$., kiedy władze ChRL, w odpowiedzi na przemówienie Michaiła Gorbaczowa wygłoszone we Władywostoku, wysłały do Moskwy delegację swego MSZ. Przebieg negocjacji był pomyślny dla obu stron, lecz koncentrował się tylko na dalekowschodniej części granic. Do drugiej fazy radziecko-chińskich rozmów już nigdy nie doszło wskutek rozpadu Związku Radzieckiego.
} 
one wobec Wspólnoty Niepodległych Państw z inicjatywą ostatecznego uregulowania kwestii granicznych ${ }^{5}$. Składana pod koniec tego roku wizyta Borysa Jelcyna w Chinach skutkowała podpisaniem kilku ważnych porozumień, między innymi: Memorandum w sprawie przewodnich wytycznych w celu wzajemnej redukcji sił zbrojnych i zwiększenia zaufania w obszarach przygranicznych.

W kwietniu 1993 r. w Pekinie odbyło się pierwsze zebranie pięciostronnej komisji, której celem było uzgodnienie traktatów granicznych. W jej pracach uczestniczyli zarówno politycy wysokiego szczebla, jak i grupy ekspertów. Prace jednej grupy koncentrowały się wokół zagadnień demarkacji granic, drugiej - demilitaryzacji obszarów przygranicznych ${ }^{6}$.

Finalizacją prac tej komisji było spotkanie przywódców Chin, Kazachstanu, Kirgistanu, Rosji i Tadżykistanu w maju 1996 r. w Szanghaju, gdzie została podpisana seria 14 dokumentów razem z Porozumieniem o zwiększeniu zaufania w obszarach przygranicznych, które razem tworzą tzw. Układ Szanghajski. Natomiast rok później, w Moskwie, liderzy „piątki szanghajskiej” podpisali Porozumienie o wzajemnym zmniejszeniu liczebności sił zbrojnych w obszarach przygranicznych, zgodnie z którym państwa powinny informować się wzajemnie o wszelkich ruchach wojsk na obszarze do $100 \mathrm{~km}$ od granicy. Ustalono również maksymalną liczbę wojsk stacjonujących w rejonach przygranicznych na 130400 osób po obu stronach granicy, przy czym należy zauważyć, iż liczba ta jest równa dla Państwa Środka z jednej strony, i łącznie dla wszystkich państw postradzieckich z nim graniczących z drugiej strony ${ }^{7}$. Utworzoną strefę przygraniczną, której szerokość wynosi $128 \mathrm{~km}$, kontrolować mają połączone patrole wojskowe ${ }^{8}$.

Multilateralny Układ Szanghajski przyspieszył proces normalizacji stosunków bilateralnych między jego uczestnikami. Choć już w marcu 1994 r. podpisano układ chińsko-kazachstański, dotyczący współpracy w dziedzinie rozwiązywania wszystkich granicznych problemów, dopiero 5 lat później głowy obu państw złożyły swoje podpisy pod ostatecznym porozumieniem. Podzielono w nim dotychczasowe sporne terytoria - $680 \mathrm{~km}^{2}$ koło przełęczy Baimurz i $380 \mathrm{~km}^{2} \mathrm{w}$ rejonie rzeki Sary-Chardy - prawie równo między umawiającymi się stronami. Nursułtan Nazarbajew mógł zatem ogłosić, że Kazachstan jest pierwszym z czterech postradzieckich państw graniczących z Chinami, które w całości unormowało z nimi swoje granice 9 .

\footnotetext{
${ }^{5}$ G. Gleanson, Policy Dimensions of West Asian Borders after the Shanghai Accord, „Asian Perspective" 2001, nr 1 .

${ }^{6}$ Ibidem.

${ }^{7}$ E. Wishnick, Russia and China: Brothers Again?, „Asian Survey” 2001, nr 5.

${ }^{8}$ A. Rashid, Dżihad. Narodziny wojującego islamu w Azji Środkowej, Warszawa 2003, s. 247.

${ }^{9}$ G. Gleanson, op.cit.
} 
Mniej dynamicznie, ale dość skutecznie postępowała współpraca w omawianej dziedzinie z Kirgistanem. Pierwsze dwustronne porozumienie o demarkacji granicy zostało podpisane w lipcu 1996 r., a wkrótce potem otwarto dwa nowe przejścia graniczne. W sierpniu 1999 r. Askar Akajew i Jiang Zemin podpisali porozumienie, które zostało określone jako „likwidujące wszystkie spory wokół granicy między dwoma państwami"10.

Wojna domowa tocząca się w Tadżykistanie w latach 1992-1997 zniweczyła oczekiwania Chin na szybkie rozwiązanie problemu tej granicy. Dopiero w sierpniu 1999 r. wysiłki dyplomacji obu państw zaowocowały podpisaniem porozumienia o demarkacji jedynie części wspólnej granicy, bowiem Pekin dalej wysuwał pretensje do około $30 \%$ terytorium tadżyckiego, leżącego wzdłuż granicy chińskiej, głównie w bogatym w złoża złota Górnym Badachszanie ${ }^{11}$. W maju 2002 r. prezydent Tadżykistanu Emomali Rachmonow przybył na zaproszenie Jiang Zemina $\mathrm{z}$ wizytą roboczą do Pekinu. W trakcie wizyty podpisano serię porozumień, najważniejszym z których wydaje się być Dodatkowe porozumienie między Chińską Republiką Ludową a Republiką Tadżykistan odnośnie granicy chińsko-tadżyckiej. W myśl tego dokumentu, Tadżykistan zobowiązał się do przekazania Chinom ok. $1000 \mathrm{~km}^{2}$. Według słów Zafara Saidowa, rzecznika prezydenta Rachmonowa, ziemie te wchodzące przedtem w skład okręgu murgabskiego Tadżykistanu, stanowią największą część z trzech terytoriów pozostającymi nadal spornymi ${ }^{12}$.

\section{Walka $z$ terroryzmem, separatyzmem i religijnym ekstremizmem}

Duże znaczenie dla przebiegu procesów politycznych, utrzymania stabilności i rozwoju w regionie ma istniejąca sytuacja narodowościowa w Chinach i republikach Azji Centralnej.

Dla Chin duże znaczenie ma geograficzne usytuowanie mniejszości narodowych. Zamieszkują one przede wszystkim tereny nadgraniczne lub położone w ich sąsiedztwie. Ponad $80 \%$ granic zachodnich przebiega przez obszary, na której nie ma wyraźnej dominacji Hanów ${ }^{13}$. Na terytorium największej w Chinach $(1646,8$ tys. $\mathrm{km}^{2}$ ) prowincji autonomicznej Xinjiang, która bezpośrednio graniczy z trzema republikami centralnoazjatyckimi, a także z ,gorącymi islamskimi punktami” - indyjskim Kaszmirem oraz z Afganistanem, zamieszkuje stosunkowo niewielka

\footnotetext{
${ }^{10}$ Porozumienie graniczne z ChRL wywołało dużą krytykę w Kirgistanie. Władzom zarzucano utrzymywanie faktu podpisania dokumentu w tajemnicy przed społeczeństwem. Mimo masowych protestów w 2002 r. parlament kirgiski zdecydował się na ratyfikację porozumienia.

${ }^{11}$ A. Rashid, op.cit., s. 247.

${ }^{12}$ Zob. szerzej: „RFE/RL Newsline”, 21.05.2002.

${ }^{13}$ S. Szynkiewicz, Mniejszości etniczne, [w:] Chiny. Przemiany państwa i spoleczeństwa w okresie reform 1978-2000, (red.) K. Tomala, Warszawa 2003, s. 355.
} 
liczba ludności: 19,2 mln, z czego aż 10,7 mln to mniejszości narodowe ${ }^{14}$. Ujgurzy, stanowiący aż 7,7 miliona, zamieszkują środkową i południową część Xinjiangu, zwłaszcza oazy ${ }^{15}$. Kazachowie stanowią 1,5 miliona i zamieszkują specjalnie dla nich utworzoną prefekturę autonomiczną oraz cztery powiaty ${ }^{16}$. Kirgizi, których jest 200 tys., w większości występują we własnej prefekturze autonomicznej. Ponad połowa ludności jest osiadła, reszta do tej pory zajmuje się koczowniczym pasterstwem. Tadżycy, stanowiąc 60 tys., występują w niektórych powiatach zachodniej części prowincji a kilka tys. Uzbeków mieszka w jej południowych miastach ${ }^{17}$. Xinjiang, będąc w przeszłości narzędziem, za pomocą którego obce państwa starały się wywierać nacisk i realizować swoje plany imperialne ${ }^{18}$, do dziś pozostaje czułym punktem Państwa Środka, przykuwającym uwagę władz chińskich.

${ }^{14}$ G. Gleanson, op.cit.

${ }^{15}$ Ujgurzy przez długi czas byli znani pod nazwami lokalnymi (Kaszgarowie, Turfanowie itd.) lub jako Taranczowie. Było to spowodowane rozbiciem terytorialnym po upadku średniowiecznego Chanatu Ujgurskiego (745-840). Państwo to znajdowało się jednak w innej części Azji, a mianowicie na terenach Syberii i Mongolii, co przyczyniło się do braku poczucia jedności. Etnonim „Ujgur” został wskrzeszony dopiero w XX w.; według jednych źródeł stało się to w 1921 r. na konferencji przedstawicieli narodów, według innych w $1935 \mathrm{r}$. w wyniku propozycji wybitnego radzieckiego turkologa S. Malova. Zob. szerzej: S. Szynkiewicz, Zróżnicowanie etniczne Chin, „Sprawy Narodowościowe” 1997, t. VI, z. 1 (10) oraz K. Hafizova, Separatizm v Sin'czjan-Ujgurskom avtonomnom rajone Kitaja: dinamika i potencial vlijanija na situaciju v Centralnoj Azii, „Centralnaja Azija i Kavkaz” 2003, nr 1.

${ }^{16}$ Można też dodać, że znaczne liczby Kazachów zamieszkują także wielonarodową prefekturę w prowincji Qinghai.

${ }^{17}$ S. Szynkiewicz, Zróżnicowanie...

${ }^{18} \mathrm{~W} 1944$ r. Ujgurzy, dzięki otrzymywanej od ZSRR broni, podjęli powstanie przeciwko Chinom i w 1946 r. została utworzona Republika Wschodnio-Turkiestańska. Jednak już w 1949 r., wskutek dojścia do władzy komunistów, Stalin stracił zainteresowanie nowo powstałą republiką, a nawet uznał ją za przeszkodę w stosunkach radziecko-chińskich. W tym samym roku, na mocy porozumienia Stalin-Mao Zedong, przywódca radziecki namówił władze Republiki Wschodnio-Turkiestańskiej do rozmów z rządem chińskim, a podczas przelotu do Pekinu samolot radziecki z liderami ujgurskimi ,uległ katastrofie". Wówczas wojsku ChRL dosyć szybko udało się opanować terytorium Xinjiangu, który znów stał się częścią Chin. Początkowo władze Państwa Środka nawet zamierzały utworzyć na wzór republik radzieckich Ujgurską Republikę Autonomiczną, ale skończyło się na prowincji z prawami autonomicznymi, z tym, że w jej nazwie słowo ,ujgurska” pojawiło się po chińskim słowie Xinjiang, co w dosłownym thumaczeniu oznacza „nowe terytoria”. Tak powstała Xinjiang - Ujgurski Region Autonomiczny na statusie prowincji. Wraz z zaostrzaniem sprzeczności chińsko-radzieckich i narastającej polemiki publicznej, w wyniku czego nastąpiło odwołanie radzieckich specjalistów z Chin (1961 r.), oraz gwałtownym pogorszeniem sytuacji materialnej ludności (spowodowanych załamaniem awanturniczego kursu ,wielkiego skoku” i w konsekwencji klęską głodu) doszło do serii zbrojnych powstań ujgurskich w Xinjiangu. W latach 1958-1972 w Xinjiangu doszło do 60 powstań, w wyniku których zginęło kilkadziesiąt tys. osób, a więcej niż 500 tys. miało trafić do obozów. Łączyło się to z masowymi ucieczkami ludności na obszary centralnoazjatyckich republik ZSRR. Z inicjatywy Chruszczowa w rejonach przygranicznych tworzone były specjalne bazy dla uchodźców z ChRL, z usług których ZSRR korzystał w działalności wymierzonej przeciwko byłemu sojusznikowi. M. Muhlisov, Dviženie za osvoboždenie Ujgurstana, „Centralnaja Azija” 1997, nr 10; F. Hamraev, Sin'czjanskij faktor i bezopastnost' Centralnoj Azii, „Centralnaja Azija i Kavkaz” 2003, nr 5. 
Ważna jest też z punktu widzenia Chin sytuacja narodowościowa w republikach Azji Centralnej. Tylko w Kazachstanie zamieszkuje blisko 220 tys. Ujgurów ${ }^{19}$. Zwarte skupiska Ujgurów występują w Kotlinie Fergańskiej, gdzie tylko w obwodzie andiżanskim Uzbekistanu mieszka ich około 14 tys., a w obwodach oszskim i czujskim Kirgistanu - około 11 tys. ${ }^{20}$

Sytuacja w Xinjiangu od dłuższego czasu pozostawała napięta. Ujgurzy nie chcieli pogodzić się z upadkiem Republiki Wschodnio-Turkiestańskiej, co skutkowało pojawieniem się licznych organizacji separatystycznych. Zaś reakcją na politykę sinizacji i przymusowej asymilacji był wybuch nastrojów religijnych i popularyzacja radykalnego islamu w regionie. Separatyści i religijni ekstremiści połączyli swoje wysiłki ogłaszając dżihad wobec Pekinu ${ }^{21}$. Uzyskanie niepodległości przez pięć republik centralnoazjatyckich nasiliło negatywne dla centrum tendencje w Xinjiangu. Do Chin zaczęły napływać doniesienia, że duża część działań separatystów i radykalnych muzułmanów przeprowadzana jest z terytorium państw Azji Centralnej, gdzie powstaje coraz więcej ugrupowań działających bez jakiejkolwiek kontroli państwowej. Najbardziej znaną z nich jest Organizacja Zjednoczonego Narodowego Rewolucyjnego Frontu Wschodniego Turkiestanu, której celem jest utworzenie niepodległego, demokratycznego, pokojowego państwa Wschodniego Turkiestanu, które złączyłoby wszystkie narodowości zamieszkujące Xinjiang. Oprócz tego działają również Ujgurstańska Organizacja Wolności, Międzyrepublikańskie Stowarzyszenie Ujgurów K. Gožamberdyeva, Fundusz Wschodniego Turkiestanu (przewodniczył mu generał wojska tureckiego Muhamet Riza Bekin), Ruch na Rzecz Niepodległości Wschodniego Turkiestanu ${ }^{22}$. Jak się okazało, znacząca część Ujgurów, którzy jeszcze w latach 80. zaangażowali się w działalność islamską - przeszli szkolenie w neobandyskich medresach pakistańskich i doskonalili swoje umiejętności w bazach wojskowych w Afganistanie - obecnie działa w ekstremistycznych ugrupowaniach islamskich, funkcjonujących na obszarze Azji Centralnej i Chin (takich jak np. Islamski Ruch Uzbekistanu).

W świetle tych faktów zrozumiałe są obawy władz ChRL przed działaniami separatystycznymi:

- ze strony (w różnym stopniu) Kazachów, Kirgizów, Tadżyków, Ujgurów i Uzbeków, zamieszkujących Chiny, na rzecz cesji części ich terytorium i przyłączenia go do poszczególnych państw centralnoazjatyckich;

${ }^{19}$ K. Hafizova, op.cit. Autorka uznaje, z przesadą, iż jest to trzecia pod względem liczebności diaspora w Kazachstanie.

${ }^{20}$ E. Aben, E. Karin, Nacional-separatistskie tendencii v SUAR KNR i problema bezopastnosti centralnoaziatskogo regiona, „Centralnaja Azija i Kavkaz” 1999, nr 4.

${ }^{21}$ G. Xing, China and Central Asia, [w:] Central Asian Security: The New International Context, (red.) R. Allison, L. Jonson, London-Washington 2001, s.162.

${ }^{22}$ E. Aben, E. Karin, op.cit. 
- ze strony Ujgurów zamieszkujących terytoria chińskie oraz republik centralnoazjatyckich na rzecz utworzenia państwa ujgurskiego;

- sił islamskich i panturkijskich na rzecz utworzenia islamskiego państwa turkijskiego na terytoriach m.in. należących do Chin.

W związku z powyższym Chiny podejmują aktywne działania na płaszczyźnie międzynarodowej zmierzające do neutralizacji wymienionych zagrożeń. Jest to przede wszystkim współpraca z państwami ze swego regionalnego otoczenia. Pierwszymi krokami w tym kierunku po demarkacji i demilitaryzacji granic było wprowadzenie do traktatów przepisów o poszanowaniu suwerennej równości, integralności terytorialnej i nietykalności granic. Trzeba dodać, że interesy Chin w tym aspekcie były zbieżne z interesami władz republik Azji Centralnej, które pragnęły:

- nawiązać dobrosąsiedzkie stosunki z sąsiadem;

- świadome bolesnych doświadczeń z przeszłości, uzyskać od Chin prawnomiędzynarodowe gwarancje swoich granic ${ }^{23}$;

- podjąć wzajemną współpracę w dziedzinie zwalczania sił godzących w ich integralność terytorialną ${ }^{24}$;

- uzyskać korzyści, w tym ekonomiczne, które wynikałyby z przyjętych zobowiązań delegalizacji ruchów ujgurskich.

W 1998 r. na szczycie „Piątki Szanghajskiej” w Ałmaty prezydent Jiang Zemin wygłosił przemówienie pod tytułem Obronić pokój i stabilność, przyczyniać się do rozwoju i rozkwitu, w którym podkreślił, że „dla utrzymania rozwoju przyjacielskiej współpracy między pięcioma państwami niezbędna jest kontynuacja zdecydowanej walki z narodowym separatyzmem, terroryzmem, przemytem broni i innym złem, które zagraża stabilności i bezpieczeństwu regionu". Państwa uczestniczące w spotkaniu wyraziły zdecydowaną chęć kontynuowania konsultacji poświęconych problemom bezpieczeństwa regionalnego i azjatyckiego, a także podkreśliły niezbędność wspólnej walki z separatyzmem etnicznym, ekstremizmem religijnym, terroryzmem międzynarodowym i przestępczością transnarodową.

Następne spotkanie szefów państw „Piątki Szanghajskiej” w sierpniu 1999 r. w Biszkeku zbiegło się w czasie z najazdem Islamskiego Ruchu Uzbekistanu na terytorium Kirgistanu, co sprawiło ogromny kłopot nie tylko gospodarzowi spotkania - Askarowi Akajewowi, ale i siłom bezpieczeństwa Kirgistanu, które przez długi czas nie

\footnotetext{
${ }^{23}$ Przede wszystkim chodzi tu o Kazachstan, gdzie pamięta się o żądaniach terytorialnych ChRL z 1969 r., które m.in. obejmowały połowę ziem kazachskich, czego konsekwencją były poważne incydenty graniczne w sierpniu tegoż roku.

${ }^{24} \mathrm{Na}$ przykład, zlikwidowana w 1997 r. jedna z wielu działających w Kirgistanie organizacji wahhabitów (radykalni islamiści), zmierzała do reaktywacji islamskiego Chanatu Kokandzkiego, który obejmowałby uzbekistańską Kotlinę Fergańską oraz południowe obszary Kirgistanu. Tym, co szczególnie zaniepokoiło władze państwowe, był fakt, iż liderem tego ugrupowania był Ujgur, pochodzący z Xinjiangu. E. Aben, E. Karin, op.cit.
} 
mogły poradzić sobie z napastnikami. Skutkowało to koncentracją tematów rozmów na zagrożeniach dla regionu ze strony terroryzmu, separatyzmu i ekstremizmu religijnego. Dla uczestników stało się jasne, że chociaż zagrożenie to dotyczy ich w różnym stopniu, to jest wspólnym ponadnarodowym problemem i dla przeciwdziałania mu potrzebne są wspólne, skoordynowane wysiłki. Wynikiem tej dyskusji było utworzenie Grupy Biszkekskiej, czyli forum współpracy szefów organów bezpieczeństwa i służb specjalnych Chin, Kirgistanu, Kazachstanu, Rosji i Tadżykistanu. W roku 2001 podpisana została Konwencja o walce z terroryzmem, separatyzmem i ekstremizmem, na mocy której została utworzona Regionalna Struktura Antyterrorystyczna ${ }^{25}$. Interesujące jest to, iż struktura ta ma działać nie tylko na potrzeby państw-członków SzOW, ale i wszystkich państw WNP26.

W sierpniu 2003 r. zostały przeprowadzone pierwsze ćwiczenia wojskowe sił zbrojnych Chin, Kazachstanu, Kirgistanu, Rosji i Tadżykistanu. Lokalizacja manewrów została wybrana nieprzypadkowo, a mianowicie - pierwszy etap został przeprowadzony w obwodzie ałmatyńskim Kazachstanu, drugi natomiast na przedmieściach miasta Yining w prowincji Xinjiang ${ }^{27}$. Manewry wojenne Interaction-2003 były drugimi w historii Chin, w których siły zbrojne Państwa Środka przeprowadzały ćwiczenia poza własnymi granicami ${ }^{28}$. Widoczne jest dążenie do koordynacji działań ChRL z państwami postradzieckimi również i w dziedzinie militarnej, która ewentualnie może być wymierzona przeciwko siłom „trzech postaci zła”"29.

Oprócz gwarancji multilateralnych otrzymanych w ramach SzOW, Chiny starają się uzyskać gwarancje dla swej polityki w omawianej dziedzinie od poszczególnych państw Azji Centralnej, co udało się Chinom osiągnąć podczas wizyt szefa MSZ Chin Li Zhaoxinga, który we wrześniu 2003 r. przybył kolejno do Tadżykistanu, Uzbekistanu i Kirgistanu. Pierwsze dwie wizyty skutkowały podpisaniem porozumień o współpracy w dziedzinie zwalczania terroryzmu, separatyzmu i ekstremizmu. Ostatnia skończyła się podpisaniem traktatu o współpracy i przyjaźni. Należy zauważyć, iż Pekin zawsze zabiega o to, aby w końcowym wspólnym dokumencie ChRL i republik centralnoazjatyckich znalazł się nie tylko zapis o potępieniu przez strony działań separatystycznych, ale i o uznaniu dla polityki ,jednych Chin”.

\footnotetext{
${ }^{25} \mathrm{http}: / /$ www.rncpec.fareast.ru (15.01.2004).

${ }^{26}$ R. Cutler, Did Putin Shanghai Bush?, „Central Asia - Caucasus Analyst”, 04.07.2001.

${ }^{27}$ C. Carlson, Central Asia: Shanghai Cooperation Organization Makes Military Debut, [@:] http://www.rferl.org (15.01.2004).

${ }^{28}$ Pierwszy raz miało to miejsce rok wcześniej, podczas wspólnych ćwiczeń sił zbrojnych ChRL i Kirgistanu.

${ }^{29}$ Jest to sformułowanie stosowane przez władze chińskie, określające terroryzm, separatyzm i ekstremizm.
} 
Chiny usilnie zabiegają także o niedopuszczenie do powstawania w republikach centralnoazjatyckich ugrupowań ujgurskich oraz o delegalizację już istniejących, jak też zaniechanie jakichkolwiek opinii krytycznych wobec polityki Chin w Xinjiangu. Ilustruje to wystosowanie protestu ChRL do MSZ Kirgistanu w sprawie publikacji przez kirgiską gazetę „Res Publica” artykułu opisującego powstania ujgurskie w chińskim mieście Yining. Według ChRL, sposób, w którym autor artykułu opisywał te wydarzenia, stanowi nie tylko „skandaliczne mieszanie się w sprawy wewnętrzne państwa”, ale i „głębokie urażenie uczuć obywateli Chin"30. Z kolei szczodrze odwdzięczają się w zamian za przychylne ChRL kroki, m.in. udzielając pomoc techniczną i militarną dla wojska i służb granicznych Kirgistanu, Kazachstanu i Uzbekistanu.

Włączenie się Chin do koalicji antyterrorystycznej, która powstała po wydarzeniach 11 września, znany politolog i amerykanista z Uniwersytetu Pekińskiego - Jin Canrong - skomentował następująco: nastąpiło to „po pierwsze - ze względu na rację stanu, po drugie - ze względu na własne problemy z terrorystami" ${ }^{31}$. Władze Chin w świetle skali sympatii i aprobaty dla stanowiska władz USA ze strony społeczności międzynarodowej, a także sposobu prezentacji idei międzynarodowego aliansu antyterrorystycznego przez Biały Dom (,z nami albo przeciwko nam”), nie miały możliwości wyboru ani grania na zwłokę. Zareagowały zatem ,ucieczką do przodu”, udzielając tej idei poparcia, tym bardziej, że leżało to $\mathrm{w}$ ich interesie, otwierało przed dyplomacją chińską nowe możliwości działania i szanse, chociaż rodziło też pewne zagrożenia ${ }^{32}$. Waszyngton, niejako w podziękowaniu, poinformował Chiny w sierpniu 2002 r. o wpisaniu Islamskiego Ruchu Wyzwolenia Turkiestanu na listę ugrupowań terrorystycznych, czego - podobnie jak w przypadku wielu innych organizacji separatystycznych w Xinjiangu - od lat domagała się strona chińska ${ }^{33}$.

\section{Współpraca gospodarcza}

W latach 80. XX w. granica między ZSRR a ChRL należała do najbardziej zmilitaryzowanych w świecie. Stosunki międzypaństwowe, także handlowe były bar-

${ }^{30}$ M. Burles, Chinese Policy toward Russia and the Central Asian Republics, s. 56-57, [@:] http://www.rand.org (11.11.2004).

${ }^{31}$ J. Rowiński, Chiny wobec wydarzeń 11 września 2001 roku: wyzwania, zagrożenia, szanse i opcje, [w:] Chiny. Rozwój społeczeństwa i państwa na przełomie XX i XXI wieku, (red.) K. Tomala, K. Gawlikowski, Warszawa 2002, s. 138.

${ }^{32}$ Ibidem.

${ }^{33}$ Liderzy ujgurskich organizacji separatystycznych zaprzeczają jakimkolwiek powiązaniom z Al-Kaidą, przyznając jednoczeście, że kierowane przez nich organizacje rzeczywiście prowadzą walkę zbrojną z „chińskimi okupantami”. L. Kleveman, The New Great Game. Blood and Oil in Central Asia, London 2003, s. 108. 
dzo ograniczone, nie było zatem potrzeby aktywniejszego rozwijania sieci połączeń drogowych, kolejowych i lotniczych pomiędzy obydwoma państwami. Stanowiło to istotny hamulec przy nawiązywaniu współpracy gospodarczej między Chinami a nowo powstałymi państwami postradzieckiej Azji Centralnej.

O polityce gospodarczej Chin w stosunku do tych państw można mówić dopiero od 1993 r. Obserwując kierunek rozwoju nowo powstałych republik Azji Centralnej władze ChRL uznały, że nawiązanie współpracy z nimi może przynieść Chinom namacalne korzyści. Początkowo była to współpraca dwustronna, polegająca przede wszystkim na rozbudowie infrastruktury - otwieraniu nowych przejść granicznych, ustanowieniu połączeń kolejowych, budowie dróg. Stopniowo te zalążki współpracy gospodarczej, gdzie udział państw ograniczał się jedynie do ułatwień w jej nawiązywaniu, zaczęły przekształcać się w poważne projekty o znaczeniu państwowym, które dla Chin nabierały wymiaru strategicznego. Fakt ten znalazł swe odbicie w przebiegu spotkań przywódców państw Azji Centralnej i ChRL, gdzie coraz częściej podejmowano dyskusje o gospodarczej stronie współpracy, którą, jak się okazało, byli zainteresowani wszyscy uczestnicy. Tak rozpoczęła się współpraca multilateralna.

Interesy gospodarcze, które Chiny zamierzają realizować w Azji Centralnej (lub z udziałem Azji Centralnej), to głównie zapewnienie sobie nieskrępowanego dostępu do surowców energetycznych oraz rozszerzanie wymiany towarowej. Pekin widzi w państwach Azji Centralnej korytarz transportowy dla swoich towarów wysyłanych na Zachód i Bliski Wschód. Proponuje też swoje terytorium jako alternatywny wobec rosyjskiego szlak tranzytowy dla towarów centralnoazjatyckich eksportowanych do Azji Wschodniej.

Kiedy w połowie lat 90 . XX w. stało się jasne, że w nowe stulecie Chiny wkroczą jako importer ropy naftowej, Pekin zwrócił się do państw Azji Centralnej w nadziei uzyskania dostępu do surowców energetycznych. Chińskie zapotrzebowanie na ropę naftową w okresie do $2010 \mathrm{r}$. oceniane jest na około 260 milionów ton, w tym deficyt - 70 milionów ton ${ }^{34}$. Chiny więc będą zmuszone do importowania znacznej ilości potrzebnego surowca, co oznacza, że polityka energetyczna Chin będzie miała coraz większy wydźwięk strategiczny. Państwa, których rozwój gospodarki zależy od importu ropy, dążą do maksymalnej dywersyfikacji źródeł importu tego surowca. Chiny, które do tej pory importowały go w 50\% z Bliskiego Wschodu (w tym w 17\% z Arabii Saudyjskiej), chcą wykorzystać możliwości regionu kaspijskiego ${ }^{35}$. Według oficjalnych danych, zasoby państw regionu kaspijskiego

${ }^{34}$ R. Zholaman, E. Aben, D. Satpaev, Geopolityczne i geoekonomiczne położenie Kazachstanu, [w:] Kazachstan: historia, społeczeństwo, polityka, (red.) T. Bodio, K. A. Wojtaszczyk, Warszawa 2000, s. 393.

${ }^{35} \mathrm{http}: / / w w w . e i a . d o e . g o v ~(12.11 .2004)$. 
ocenia się na 17-33 miliardów baryłek ropy, której produkcja już w 2002 r. wyniosła 1,6 milionów baryłek dziennie, a według prognoz ilość ta zwiększy się w 2010 r. do 3-4,7 milionów baryłek ${ }^{36}$.

Tabela 1. Zasoby ropy w państwach centralnoazjatyckich

\begin{tabular}{|l|c|c|c|}
\hline & $\begin{array}{c}\text { Rezerwy } \\
\text { (miliardy ton) }\end{array}$ & $\begin{array}{c}\text { Udział w zasobach } \\
\text { światowych }\end{array}$ & $\begin{array}{c}\text { Poziom produkcji } \\
\text { w 2001 roku } \\
\text { (miliony ton) }\end{array}$ \\
\hline Kazachstan & 1,20 & $0,9 \%$ & 40,1 \\
\hline Turkmenistan & 0,10 & $0,1 \%$ & 8,6 \\
\hline Uzbekistan & 0,10 & $0,1 \%$ & 7,4 \\
\hline
\end{tabular}

Źródło: opracowanie własne na podstawie The resource wealth burden - oil and gas sectors in the former USSR, "CES Studies”, Warsaw December 2003.

Jedno z dwóch największych przedsiębiorstw chińskich branży energetycznej, Chińska Narodowa Korporacja Naftowa (CNPC), stało się w 1997 r. głównym $(60 \%)$ udziałowcem kazachstańskiego Aktobemunaigazu - niedawno sprywatyzowanej korporacji, kontrolującej 3 najbardziej obiecujące pola roponośne Kazachstanu, których rezerwy są oceniane na 1 miliard baryłek ${ }^{37}$. W tym samym roku została podpisana umowa przewidująca budowę 2900-kilometrowego rurociągu prowadzącego znad Morza Kaspijskiego do Chin (ma zostać uruchomiony pod koniec 2005 r.). W sierpniu 2005 r. Chiny znacząco umocnily swoją pozycję na kaspijskim rynku surowców energetycznych, gdyż CNPC wygrała przetarg na 100\% akcji PetroKazachstanu - właściciela m.in. jednej z największych kazachstańskich rafinerii oraz złóż ropy w południowo-zachodniej części Kazachstanu ${ }^{38}$.

Chociaż obecna konsumpcja gazu w Chinach wynosi zaledwie 3\% ogółu spożycia surowców energetycznych, to według prognoz w 2010 r. poziom ten podwoi się $^{39}$. Jest to związane z szybkim rozwojem gospodarki, a także próbami Chin zastąpienia węgla gazem, jako mniej szkodliwym dla środowiska naturalnego ${ }^{40}$. Aby sprostać wzrostowi zapotrzebowania, Chiny będą zmuszone do zwiększenia importu tego surowca. Państwa centralnoazjatyckie posiadają wystarczające do tego

\footnotetext{
${ }^{36}$ Ibidem.

${ }^{37}$ Kang Wu, China's emergence in Central Asia: Security, Diplomatic, and Economic Interests. Forum Three: Energy and Trade in China - Central Asia Relations. April 22, 2003, [@:] http://: www.csis.org (12.11.2004).

${ }^{38}$ Zob. szerzej: A. Łoskot, Chiny umocniają sięw kazaskim sektorzenaftowym, [@:] http://www. osw.waw.pl.

${ }^{39} \mathrm{http}: / / w w w . e i a . d o e . g o v(12.11 .2004)$.

${ }^{40}$ R. Ebel (w:) China's emergence in Central Asia...
} 
celu zasoby gazu. Chiny planują budowę gazociągu o długości $4200 \mathrm{~km}$, transportującego gaz produkowany w Basenie Tarimskim do Szanghaju. Koszt jego budowy obliczany jest na 18 miliardów USD, w związku z czym pojawiły się projekty przedłużenia zachodniego końca tego gazociągu do Kazachstanu ${ }^{41}$.

Tabela 2. Zasoby gazu w państwach centralnoazjatyckich

\begin{tabular}{|l|c|c|c|}
\hline & $\begin{array}{c}\text { Rezerwy } \\
\left(\text { biliony } \mathrm{m}^{3}\right)\end{array}$ & $\begin{array}{c}\text { Udział w zasobach } \\
\text { światowych }\end{array}$ & $\begin{array}{c}\text { Poziom produkcji } \\
\text { w 2001 roku } \\
\left(\text { miliardy } \mathrm{m}^{3}\right)\end{array}$ \\
\hline Kazachstan & 1,84 & $1,2 \%$ & 11,6 \\
\hline Turkmenistan & 2,01 & $1,3 \%$ & 51,6 \\
\hline Uzbekistan & 1,87 & $1,2 \%$ & 57,4 \\
\hline
\end{tabular}

Źródło: opracowanie własne na podstawie The resource wealth burden - oil and gas sectors in the former USSR, "CES Studies", Warsaw December 2003.

Handel i inwestycje są dwoma najbardziej widocznymi przejawami obecności gospodarczej Chin w Azji Centralnej. Państwa centralnoazjatyckie eksportują do Chin surowce naturalne, a importują towary konsumpcyjne. Kazachstan eksportuje surowce energetyczne, żelazo, stal, miedź, Kirgistan - miedź oraz złom, a Uzbekistan - bawełnę oraz surówkę bawełnianąa ${ }^{42}$. Chińskie towary konsumpcyjne stanowią dużą część importu Kazachstanu, Kirgistanu i Uzbekistanu. Większość z tych towarów została wyprodukowana w północno-zachodniej części Chin. Jeszcze w 1993 r. wartość eksportu Xinjiangu do republik centralnoazjatyckich stanowiła 240,2 mln USD, co wynosiło 3,5\% PKB prowincji Xinjiang ${ }^{43}$. Chociaż stanowi to tylko $0,25 \%$ całego handlu zagranicznego $\mathrm{ChRL}^{44}$, za intensyfikacją powiązań gospodarczych między Azją Centralną a Xinjiangiem przemawiają względy polityczne. Władze chińskie uważają bowiem rozwój gospodarczy tego regionu za panaceum na wszelkiego rodzaje separatyzmy. Między innymi dlatego właśnie Xinjiang otrzymał poniekąd status przyczółka dla ekspansji gospodarczej Chin na Zachód ${ }^{45}$.

${ }^{41}$ Ibidem.

${ }^{42}$ M. Blaxall, China's Emergence in Central Asia ...

${ }^{43} \mathrm{~S}$. Tang, Economic Integration in Central Asia: the Russian and Chinese Relationship, „Asian Survey" 2000, nr 2.

${ }^{44}$ P. Andrews-Speed, S. Vinogradov, China's Involvment in Central Asia Petroleum: Covergent or Divergent Interests?, „Asian Survey” 2000, nr 2.

${ }^{45}$ Xinjiang Becomes Bridgehead for Trade Ties with Central Asia, [@:] http://www.china.org.cn. 
Dużo uwagi władze ChRL poświęcają wspieraniu projektów transportowych, mogących im dać jak najkrótszy, korzystny i bezpieczny dostęp do rynków Europy i Bliskiego Wschodu. Dzięki otwartemu w maju 1996 r. 295-kilometrowemu połączeniu kolejowemu Meszhed-Serachs-Tedżen, Chiny otrzymały możliwość komunikacji z Iranem, a tym samym wyjście m.in. do Zatoki Perskiej wprost poprzez Azję Centralną ${ }^{46}$. Dzięki innym zrealizowanym projektom kolejowym już w tej chwili możliwy jest transport towarów z chińskiego portu Lianyungang przez Ałmaty do Rotterdamu. Ten promowany przez Chiny szlak jest o 8000 km krótszy od tradycyjnego sposobu przewozu towarów drogą morską z Europy do Azji przez Kanał Sueski ${ }^{47}$.

Znaczne korzyści polityczne i gospodarcze Pekin upatruje w zintensyfikowaniu handlu republik Azji Centralnej z państwami Azji Wschodniej przez swoje terytorium. ChRL dysponują dwoma strategicznymi korytarzami transportowych, przez które mogłaby zachodzić ta wymiana: drugiej Trans-Euroazjatyckiej Kolei i wybudowanej w 1997 r. autostrady łączącej Uzbekistan, Kirgistan i Xinjiang ${ }^{48}$.

\section{Interesy polityczne}

Chociaż po rozpadzie Związku Radzieckiego świat przestał być dwubiegunowy i w tym sensie stał się bardziej bliski systemu multipolarnego, to jednak pozycja Stanów Zjednoczonych pozostaje dominującą. Dlatego Chiny postrzegając obecną pozycję USA i ich siłę ekonomiczną, polityczną i militarną jako zagrażającą ich interesom i aspiracjom, są gorącym orędownikiem idei świata wielobiegunowego. $Z$ chińskiego punktu widzenia multipolarny system bezpieczeństwa jest nader korzystny, gdyż współdziałania między państwami w jego ramach są nie tylko wzajemnie korzystne, ale także mają większy efekt prewencyjny. Multipolarność obniża bowiem możliwość stosowania przymusu przez jedno potężne, rozwinięte państwo, takie jak USA wobec państwa mniej rozwiniętego, jak Chiny ${ }^{49}$.

Chiny pragną więc pozyskać państwa Azji Centralnej dla własnej koncepcji bezpieczeństwa, a forum SzOW traktują jako instrument jej nagłaśniania, przeciwstawiając ją unilateralnym, amerykanocentrycznym ideom dominacji USA ${ }^{50}$.

\footnotetext{
${ }^{46}$ Ta trasa łączy szlaki kolejowe Iranu i regionu Zatoki Perskiej ze szlakami kolejowymi Azji Centralnej oraz Rosji, Chin, Turcji, Pakistanu i Europy. Zob. szerzej S. Kardaś, Szlaki komunikacyjne i transport, [w:] Turkmenistan: historia, społeczeństwo, polityka, (red.) T. Bodio, Warszawa 2005, s. 539.

${ }^{47}$ M. Burles, op.cit., s. 38.

${ }^{48}$ S. Tang, op.cit.

${ }^{49}$ M. Burles, op.cit., s. 29-30.

${ }^{50}$ Zob. szerzej: D. Finkelstein, China's Emergence in Central Asia ...
} 
Odpowiedzią Chin na zagrożenia wynikające dla ich interesów i aspiracji z dominującej pozycji USA jest także realizowana konsekwentnie od drugiej połowy lat 80. polityka „dobrego sąsiedztwa”. Zakłada ona, że interesy narodowe, a nie kryteria ideologiczne powinny definiować politykę Chin wobec innych państw, szczególnie sąsiedzkich. Stosując tę politykę, Chiny wzmocniły powiązania z innymi państwami regionu Azji i Pacyfiku, a także zintensyfikowały lub nawiązały stosunki z państwami Europy i Ameryki Łacińskiej. Innymi słowy, Chiny próbują przeciwstawić się zagrożeniu płynącemu z supermocarstwowej pozycji USA, tworząc szeroką siatkę powiązań regionalnych i globalnych. Te powiązania nie są wystarczające, aby całkowicie zneutralizować ekonomiczną, militarną i polityczną siłę Stanów Zjednoczonych w najbliższej przyszłości, ale powodują uzyskanie przez Chiny alternatywnych źródeł handlu, technologii, inwestycji i poparcia politycznego. Właśnie w takim kontekście powinno być oceniane, według Marka Burlesa, zaangażowanie Chin w Azji Centralnej ${ }^{51}$.

Pojawienie się sił wojskowych USA w Azji Centralnej nie mogło nie spowodować reakcji Chin. Według Dawida Finkelsteina ewolucje poglądów Chin w tej dziedzinie można podzielić na następujące etapy ${ }^{52}$ :

1. Szok i obawa co do możliwych zagrożeń dla interesów Chin w tym regionie. Chiny nie mogły uwierzyć w to, że Rosja tak szybko zgodziła się wpuścić USA na terytorium swoich szczególnych interesów. Według Fiony Hill było to motywowane chęcią Rosji, świadomej swoich słabnących pozycji w porównaniu z ChRL, wprowadzenia na arenę następnego gracza, który by nie tylko osłabił pozycję Chin w Azji Centralnej, ale i pośrednio wzmocnił pozycję Rosji. Założenie rosyjskiej bazy wojskowej Kant w Kirgistanie w grudniu 2002 potwierdza tylko ten punkt widzenia ${ }^{53}$.

2. Uświadamianie przez analityków chińskich ewentualnych korzyści mogących płynąć z obecności USA w Azji Centralnej. Udana operacja koalicji mogłaby stabilizować region i służyć realizacji niektórych bieżących i średniofalowych interesów chińskich, takich jak np. likwidacja działających w regionie grup ekstremistycznych.

3. Ponowny niepokój z powodu obecności USA. Dyskusje koncentrują się na pytaniach: jak długo Stany Zjednoczone zamierzają pozostać w regionie, jaki wpływ będzie miała ich obecność i czy nieustanne problemy USA w Iraku będą tożsame z utratą zainteresowania Stanów Zjednoczonych Azją Centralną.

Obecność USA w regionie nie mogła nie przykuwać uwagi Pekinu. Amerykańskie siły zbrojne znajdowały się zaledwie kilkaset kilometrów od chińskiej granicy.

\footnotetext{
${ }^{51}$ M. Burles, op.cit., str. 34.

${ }^{52}$ D. Finkelstein, China's Emergence in Central Asia ...

${ }^{53}$ F. Hill, China's Emergence in Central Asia....
} 
Przy tym - w odróżnieniu do Rosji - Chiny nie były uważane za stronę „bezpośrednio poszkodowaną" na skutek pojawienia się baz amerykańskich w regionie, stąd nie mogły liczyć na swoistą „rekompensatę polityczną" 54 . Za negatywne tendencje w regionie Pekin uznał nie tylko zbliżenie amerykańsko-rosyjskie, które jego zdaniem „poszło za daleko”, ale i zajęcie przez niektóre państwa centralnoazjatyckie pozycji zdecydowanie proamerykańskiej ${ }^{55}$. Następstwem tego była marginalizacja SzOW i osłabienie pozycji Chin w regionie.

Dyplomacja chińska podjęła olbrzymi wysiłek na rzecz przezwyciężenia zaistniałej sytuacji. Wraz z Rosją, również zaniepokojoną perspektywą utraty obszaru swoich tradycyjnych wpływów, przystąpiła do naciskania na państwa centralnoazjatyckie w celu rewaloryzacji ich polityki zagranicznej. Przejawiało się to zarówno podczas spotkań dwustronnych, jak i szczytów SzOW. Działania Pekinu i Moskwy osiągnęły zamierzony cel - w czerwcu 2005 r. Szanghajska Organizacja Współpracy w pełnym składzie wystosowała do Waszyngtonu oficjalne zapytanie w sprawie krańcowego terminu wycofania z regionu sił zbrojnych USA ${ }^{56}$. Zapewne z przyjemnością powitał Pekin informację zarówno o żądaniu Islama Karimowa wycofania sił amerykańskich z uzbeckiej bazy w Chonabadzie w terminie 180 $\mathrm{dni}^{57}$, jak i zapewnienia niedawno wybranego prezydenta Kirgistanu Kurmanbeka Bakijewa o konieczności renegocjacji ze Stanami Zjednoczonymi umowy o dzierżawie bazy lotniczej „Manas”.

Mimo rosnącego znaczenia regionu centralnoazjatyckiego dla ChRL, Pekin przykłada jednak nadal większe znaczenie do stosunków łączących go z Moskwą. Będąc świadomym tego, jak drażliwym tematem jest dla Rosji jej pozycja w regionie, Chiny podczas spotkań i wizyt oficjalnych starają się zapewnić Moskwę o tym, że nie zamierzają wypełnić pustki geopolitycznej powstałej po jej odejściu ${ }^{58}$. Chiny starannie kształtują swą politykę centralnoazjatycką, tak aby nie „urazić” Rosji ${ }^{59}$. Shiping Tang uważa, że reguły gry zastały ustalone według następującej zasady: Rosja nie

\footnotetext{
${ }^{54}$ J. Rowiński, Chiny..., s. 138.

${ }^{55}$ Ibidem.

${ }^{56}$ O czerwcowym szczycie SzOW zob. szerzej G. Sadowski, Smoczy apetyt, „Wprost”, 31.08.2005

${ }^{57}$ Chociaż oficjalnie władze uzbeckie temu zaprzeczają, powszechnie uważa się, że przyczyną tego żądania było pogłębiające się pogorszenie stosunków na linii Taszkent-Waszyngton. Dołączenie się USA do grupy państw żądających niezależnego śledztwa międzynarodowego w sprawie masakry ludności cywilnej w Andiżanie prawdopodobnie było zaledwie pretekstem do dawno planowanego zwrotu w polityce zagranicznej Uzbekistanu.

${ }^{58}$ S. Tang, op.cit.

${ }^{59}$ Uważa się nawet, że Chiny nie przystąpiły do „pipeline battle”, dopóki obecność Zachodu w regionie nie stała się oczywista. Ale nawet jako jeden z licznych „graczy” Chiny działają na tej płaszczyźnie bardzo ostrożnie - np. podczas negocjacji dotyczących budowy gazociągu z Turkmenistanu do Chin Pekin wyraził gotowość do spełnienia szeregu warunków, m.in. budowy dodatkowej gałązi biegnącej z Chin do rosyjskiego Irkucka.
} 
chcę zwiększonej obecności Chin w regionie, a Chiny nie podejmują inicjatyw bez poparcia Rosji lub przynajmniej akceptacji z jej strony ${ }^{60}$. Według Dmitrija Trenina związane jest to z tym, że Chiny chcą, aby to właśnie Rosja pełniła w Azji Centralnej funkcję stabilizacyjną, przynajmniej dopóty, dopóki one same nie będą w stanie zastąpić jej w tej funkcji ${ }^{61}$.

Chociaż Chiny nie wyrażały zainteresowania w rozszerzeniu swojej strefy wyłącznych wpływów na Azję Centralną i ograniczały się do realizacji interesów zdefiniowanych jako wieczyste, to wydaje się jednak, że zwiększająca się potęga polityczna, gospodarcza i militarna Państwa Środka może zachęcić je do głębszego zaangażowania w sprawy centralnoazjatyckie.

\section{Zakończenie}

Realizacja polityki chińskiej w Azji Centralnej napotyka na rozmaite ograniczenia i problemy. Po pierwsze jest to postrzeganie Chin przez elity władzy politycznej republik centralnoazjatyckich jako „hegemon-in-waiting” i wynikająca stąd podejrzliwość wobec chińskich intencji i poczynań. Po drugie, jest to kwestia ograniczonych środków, które Chiny mogą zainwestować w Azji Centralnej oraz problem skromnych możliwości ich akomodacji. Po trzecie, chociaż Chiny robią postępy w poznawaniu omawianego regionu, jednak ich możliwości dostępu do przedstawicieli elit władzy republik centralnoazjatyckich są nadal skromne, szczególnie w porównaniu z tymi, które posiada Rosja ${ }^{62}$.

Najbardziej dynamicznie udało się Chinom rozwinąć stosunki z Kazachstanem, przede wszystkim w dziedzinie handlu. Jednak nie należy oczekiwać, że to właśnie Kazachstan jest pierwszym kandydatem do zagoszczenia w strefie dominacji Chin. Stoją na przeszkodzie temu nie tylko dosyć skromne możliwości inwestycyjne Chin w porównaniu z takimi gigantami jak Mobil, Shell, Total, BP, Statoil, które aktywnie zajmują „nowe terytoria”, ale i taki czynnik jak polityka kazachstańskich władz, powodowana też dużą rosyjską mniejszością, która jest nieprzychylna zwiększającej się obecności Chin w regionie.

Również z Kirgistanem Chinom udało się nawiązać ścisłą współpracę. Niektórzy eksperci, biorąc pod uwagę to, że ChRL stała się największym eksporterem i jednym z największych importerów republiki uważają, że w ciągu następujących kilku lat Chiny mają szanse w całości zdominować gospodarkę Kirgistanu. Jednak stoi temu na przeszkodzie fakt, że Kirgistan potrzebuje inwestycji dla skuteczne-

${ }^{60}$ S. Tang, op.cit.

${ }^{61}$ D. Trenin, China's Emergence in Central Asia: Security, Diplomatic, and Economic Interests. Forum Two: Counterterrorism, Stability, Internal Security, and China-Central Asia Relations, March 5, 2003, [@:] http://www.csis.org/ (12.11.2004).

${ }^{62}$ Ibidem. 
go zakończenia transformacji swojej gospodarki, a Chiny są dosyć powściągliwe $\mathrm{w}$ inwestowaniu w państwie tak skromnie wyposażonym w surowce naturalne.

Stosunki Chin z Tadżykistanem mają dosyć ograniczony wymiar. Ma na to wpływ nie tylko niejasna sytuacja polityczna w kraju prezydenta E. Rachmonowa, ale także nierozstrzygnięty spór terytorialny między państwami.

Uzbekistan i Turkmenistan są państwami, gdzie wpływy chińskie są najmniejsze w porównaniu z pozostałymi republikami centralnoazjatyckimi. Niewątpliwe znaczenie ma tu oddalenie geograficzne tych państw od ChRL. Oprócz tego na podkreślenie zasługują ambicje Uzbekistanu do ekspansji własnych wpływów w regionie i wynikająca stąd niechęć do potencjalnego rywala. Turkmenistan natomiast bardziej wydaje się być podatny na wpływy irańskie.

Jak dalej będą rozwijać się stosunki Chin z Azją Centralną? Prawie wszyscy analitycy zgadzają się z tym, że wpływy chińskie będą rosły, różnią się tylko w poglądach jak szybko, do jakiego stopnia i do jakiego zasięgu geograficznego. Zbigniew Brzeziński uważa, że w perspektywie znaczenie Chin w tym regionie zrówna się z tym, które mają Rosja oraz Stany Zjednoczone. Utrzymuje, że Chiny mają szansę wyjść na dominującą pozycję, chociażby ze względu na znaczenie, które władze ChRL przydają swojej kompanii „Go West”, a także ze względu na to, że gospodarka chińska rozwija się pięć razy szybciej od rosyjskiej ${ }^{63}$. Mark Burles łagodzi wymowę takich prognoz, twierdząc, że jest bardzo prawdopodobne, że Chiny uzyskają w przyszłości dominującą rolę ekonomiczną i polityczną, ale tylko w niektórych państwach lub nawet regionach Azji Centralnej. Nawet jeżeli Chinom uda się utrzymać dynamiczny rozwój gospodarczy, który - jak uważa Burles - jest jednym z koniecznych warunków zwiększania ich wpływów, jest nieprawdopodobne, by udało im się rozciągnąć wpływy na całą Azję Centralnąa

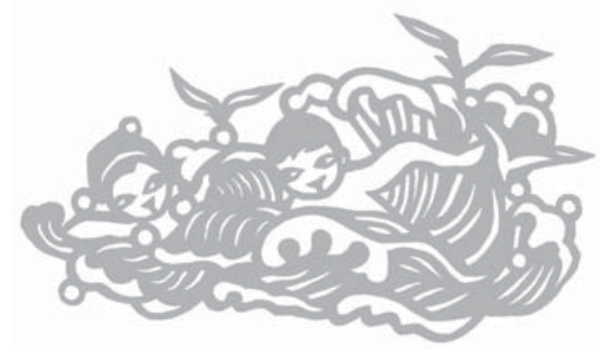

${ }^{63}$ Z. Brzeziński, China's Emergence in Central Asia...

${ }^{64}$ M. Burles, op.cit., s. 52. 